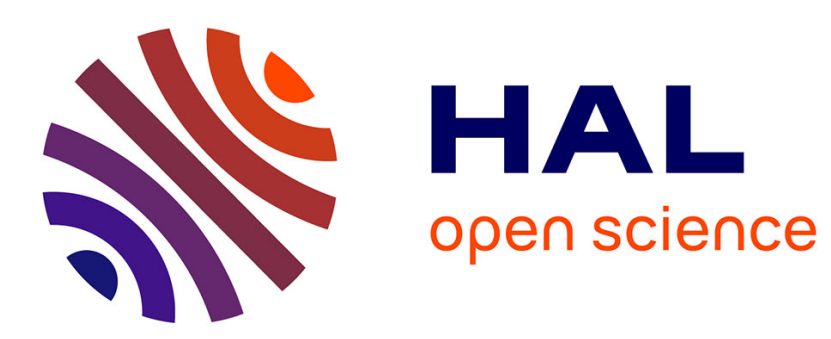

\title{
Active tectonics and human survival strategies
}

Geoffrey King, Geoffrey Bailey, Derek Sturdy

\section{To cite this version:}

Geoffrey King, Geoffrey Bailey, Derek Sturdy. Active tectonics and human survival strategies. Journal of Geophysical Research: Solid Earth, 1994, 99 (B10), pp.20,063-20,078. 10.1029/94JB00280 . hal00158848

\section{HAL Id: hal-00158848 \\ https://hal.science/hal-00158848}

Submitted on 3 Feb 2021

HAL is a multi-disciplinary open access archive for the deposit and dissemination of scientific research documents, whether they are published or not. The documents may come from teaching and research institutions in France or abroad, or from public or private research centers.
L'archive ouverte pluridisciplinaire $\mathbf{H A L}$, est destinée au dépôt et à la diffusion de documents scientifiques de niveau recherche, publiés ou non, émanant des établissements d'enseignement et de recherche français ou étrangers, des laboratoires publics ou privés. 


\title{
Active tectonics and human survival strategies
}

\author{
Geoffrey King \\ Institut de Physique du Globe, Strasbourg, France
}

Geoffrey Bailey

Department of Archaeology, University of Cambridge, Cambridge, England

Derek Sturdy

Department of Archecological Sciences, University of Liverpool, Liverpool, England

\begin{abstract}
Tectonic movements continuously remould the surface of Earth in response to plate motion. Yet such deformation is rarely taken into account when assessing landscape change and its impact on human land use, except perhaps as an occasional hazard to human life or a temporary disruption in the longer term patterns of human history. However, active tectonics also create and sustain landscapes that can be beneficial to human survival, forming a complex topography of potentially fertile sedimentary basins enclosed by mountain barriers that can facilitate the control and exploitation of food resources, especially animal prey. We discuss the tectonic history of northwest Greece and show how the Paleolithic sites of the region are located to take advantage of tectomically created features at both a local and a regional scale. We suggest that the association of significant concentrations of early Paleolithic sites with tectonically active regions is not coincidental and that on the longer time spans of human biological evolution, active tectonics has been an important selective agent contributing to the development of the human species as an intelligent predator.
\end{abstract}

\section{Introduction}

Tectonic processes and human social and economic changes are usually assumed to operate on such disparate time scales that there is virtually no overlap between them. Large-scale uplift or subsidence, driven by the motions of the continental plates, seems to operate too slowly or to belong to a geological past too distant to have any relevance to major episodes of human development. Short-lived events such as earthquakes and volcanoes clearly have a visible impact, especially if they result in spectacular episodes of destruction, as at Pompeii or the Bronze Age settlement of Akrotiri on the island of Thera, but they are rarely perceived as being other than temporary or disruptive in effect, unless they seem to trigger far-reaching social changes. The explosion of Thera volcano in the Aegean in the mid second millennium B.C. has excited unusual interest and investment of research effort because of its potential role in the downfall of Minoan civilization and suggested links with the myth of Atlantis. However, it is now clear that the eruption occurred later than the main destruction levels in most of the Minoan palaces and that its impact in human terms was much more restricted [Hardy et al., 1989]. Tectonic changes over longer time spans are sometimes cited in the anthropological literature, but here too the effects are usually described in negative terms. For example, Moseley [1983] and Moseley and Feldman [1988] have argued that tectonic uplift on the Peruvian coastline has resulted in repeated disruption of prehistoric irrigation canals and that Andean civilization must

Copyright 1994 by the American Geophysical Union.

Paper number 94JB00280.

0148-0227/94/94JB-00280\$05.00 therefore have been founded on maritime fishing rather than crop agriculture. In general, however, the impact of environmental processes on human palaeoeconomies is described without reference to tectonics. Fertility or barrenness of soils, erosion or deposition of sediment, and droughts or floods are most readily explained by the variable influence of climate, or in recent millennia of human interference, acting on an unchanging geological substratum.

Here we argue that this perspective is too restricted. Changes in landscape geometry caused by deformation of the solid earth can determine the way in which climate affects the landscape and the way in which the landscape in its turn affects and is affected by human activity. In many parts of the world, an appreciation of tectonics is needed to understand the distribution of agricultural soils or of animal herds. On the longer time scales of prehistory, tectonically driven landscape change may become an active agent of selection, creating pressures or opportunities for changes in behavior. It is easy to that tectonic uplift can destroy an environment by triggering erosion, but active deformation is by no means always negative in effect. Tectonic subsidence can create well-watered sediment traps, while volcanic eruptions can renew the supply of fertile agricultural soils. Uplift and subsidence also create natural barriers to animal movement that can be exploited by humans. It is interesting to note that many early Paleolithic sites around the Mediterranean (Figure 1) are in regions of tectonic activity, and sites in the East African Rift Valley and Sub-Himalayan India provide further examples. Undoubtedly, the ease of site discovery can be assisted by tectonic changes. Tectonically active areas are those most likely to develop thick, rapidly formed sequences of terrestrial sediments favoring burial and fossilization of archacological evidence, fol- 


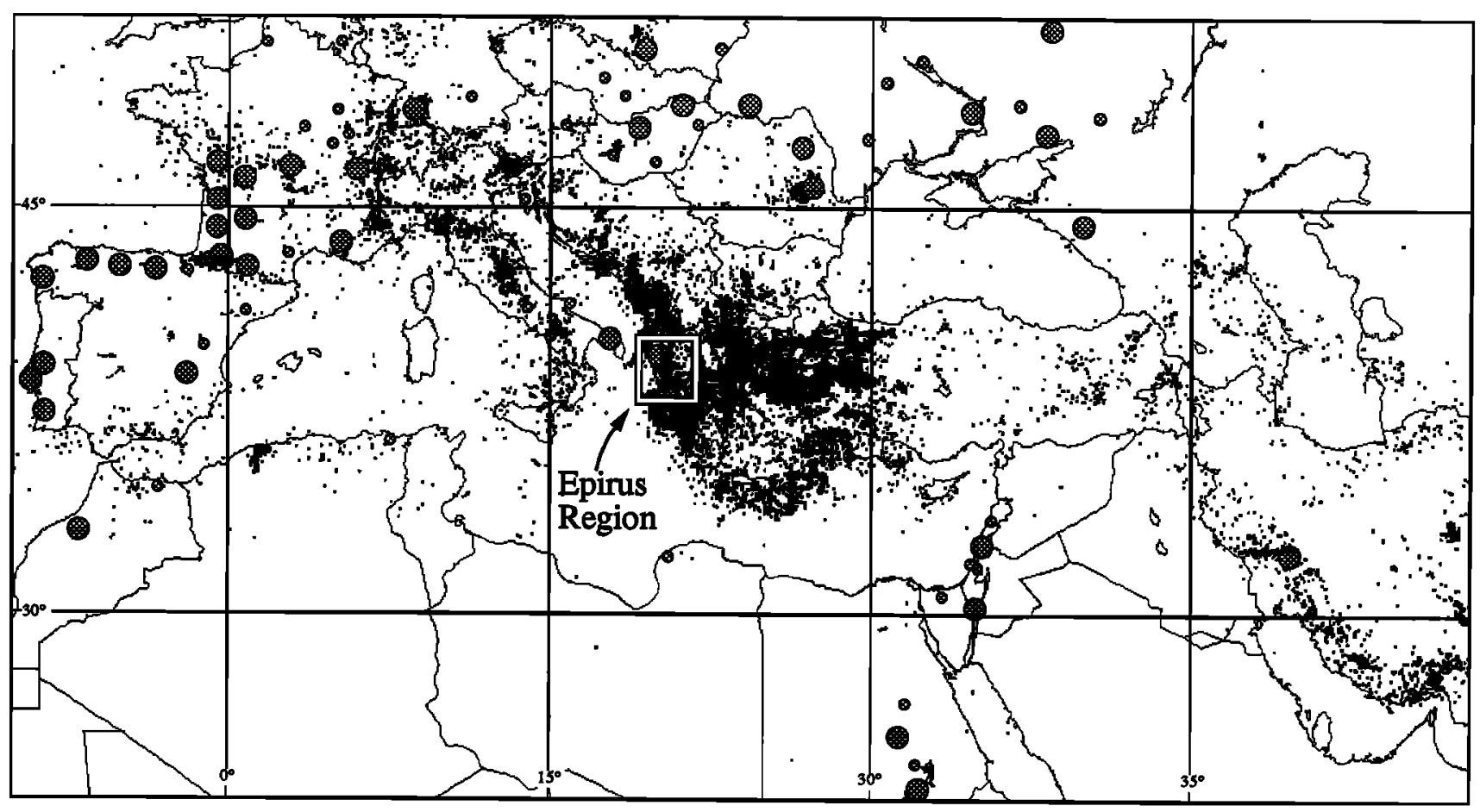

Figure 1. Distribution of Upper Paleolithic sites and seismicity in Europe and the Middle East. Large grey-shaded circles ropresent groups of sites, and smaller circles are individual sites (caves and open air between 24 and $15 \mathrm{kyr}$ [after Madeyska, 1990]. The seismicity (epicenters represented by solid dots) is plotted from data compiled by the National Earthquake Information Center of the U.S. Geological Survey and shows all events above magnitude 4 between 1970 and 1989. Since small earthquakes are only reliably looated where there is a good network of local stations, the total number of epicenters does not necessarily reflect activity. Thus France, where a large number of small events are well located, is not more active than East Africa, where no small events are well recorded. Nevertheless, seismicity does indicate ongoing tectonic deformation, and any region of the map where epicenters appear certainly experiences tectonic deformation with rates that may be archaeologically significant.

lowed by rapid erosion and exposure to discovery. But the reverse is true, and tectonically active regions can destroy or obscure human evidence within decades or centuries. In our discussion of the Paleolithic sequence in Epirus, we discuss why ease of discovery is not the main reason that a correlation between early human settlement and tectonic activity is found.

\section{Active Tectonics}

Since the advent of plate tectonics, it has been evident that deformation of Earth is a continuing process. Relative motions at major plate boundaries have rates that can approach $20 \mathrm{~cm} \mathrm{yr}^{-1}$ and are commonly greater than $1 \mathrm{~cm} \mathrm{yr}^{-1}$ [DeMets et al., 1990]. In oceanic regions deformation can be localized to ridges, trenches, or transform faults with widths $<100 \mathrm{~km}$. Where plate boundaries cross continental crust, contraction, extension, or strike-slip motion can be spread over regions with widthe $>1000 \mathrm{~km}$.

Deformation also occurs at a wide range of scales. Over long periods of time, vast areas rise to form mountains such as the Alps or the Himalayas or subside to form basins or valleys such as the Aegean trough or the Red Sea rift. These features result from the cumulative effect of motion on many smaller features which individually may have a shorter existence but nonetheless exhibit substantial rates of motion when active. At scales of 5-50 km, motion can be very rapid, and uplift or subsidence of $100 \mathrm{~m}$ is possible within historic times. In re- gions of contraction, not all motion is progressive uplift; in regions of extension, not all motion is progressive subsidence. Areas of local uplift and local subsidence can lie close together, only kilometers apart, or even hundreds of meters or less.

Temporal variability occurs and can cause tectonic activity to be overlooked, particularly on smaller features. Even features such as Death Valley and the associated Panamint Valley in the western United States show little activity at present. However, they are not dead. Ample morphological evidence exists that several major earthquakes have occurred in the last 10-15 kyr [Zhang et al., 1990]. Similarly, historical data indicate that features between Turkey and Iran have had periods of major earthquakes lasting for tens of years separated by centuries of inactivity [Ambraseys, 1989]. In the absence of direct observations from instruments or historical reports, the best evidence for tectonic activity is commonly evidence for local disruption of rivers or evidence for local regions of erosion and deposition of sediment.

Human modes of land use can be affected by modest amounts of uplift or subsidence. Even very small rates of movement can be significant in modifying water table levels in the short term (hundreds or thousands of years) or in creating substantial morphological features in the longer term. Overall, the effects of tectonic deformation may be expected to be widespread and not just restricted to regions where tectonic activity is widely acknowledged to be sufficiently high to cause a major earth- 

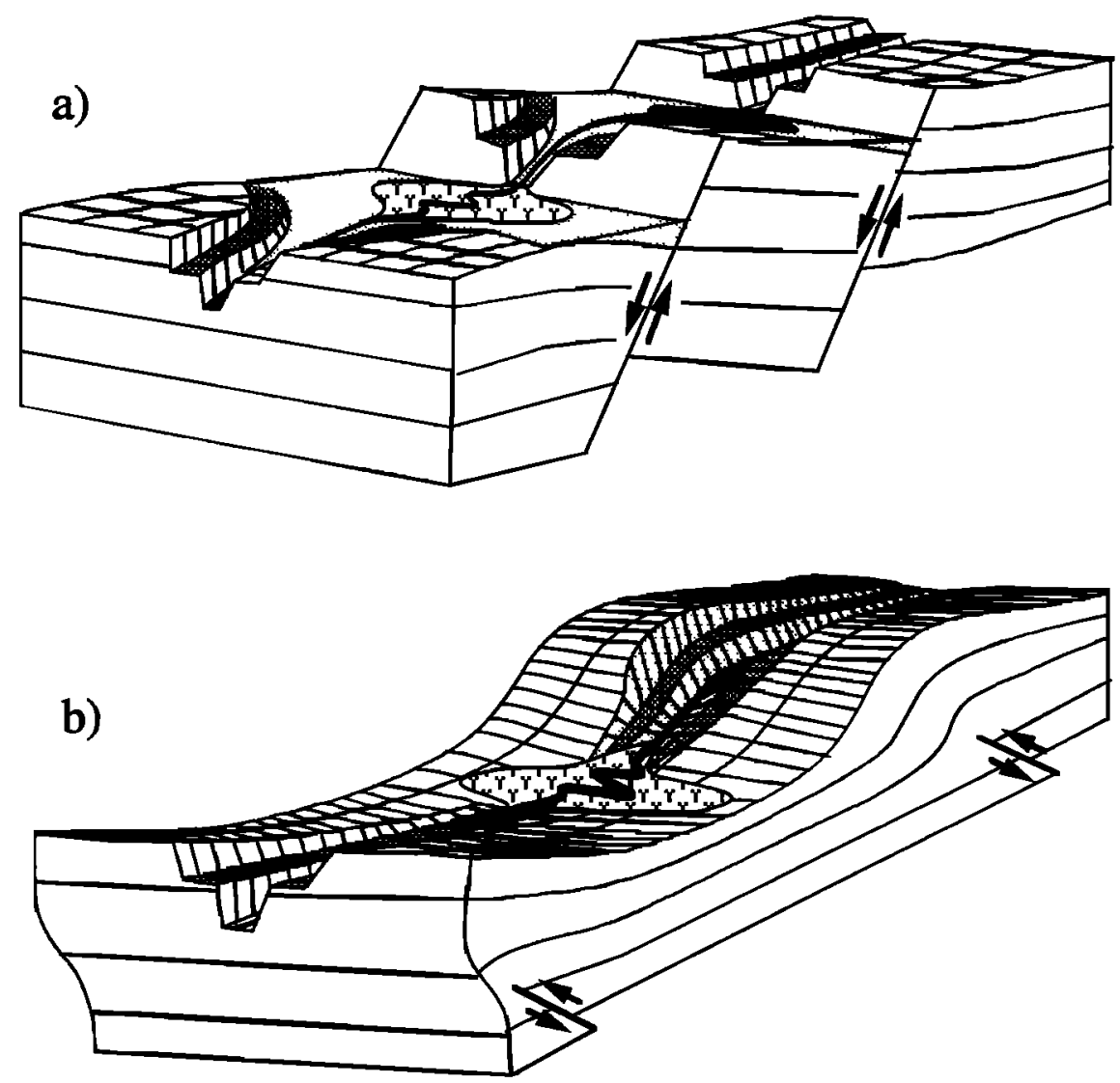

Figure 2. Schematic illustration of the way in which (a) active normal faulting and (b) reverse faulting create downcutting and the formation of terraces plus local ponds of sediment. While the most straightforward conditions are produced when the drainage crosses dip-slip structures at $90^{\circ}$, similar effects can be found when rivers run subparallel to active features or are created by features that are largely strike slip. Whatever the exact tectonic conditions, locally severe topography and local, fertile sediment traps are created and maintained by active tectonics. Such small-scale features do not persist for long when tectonic activity diminishes.

quake hazard under normal conditions. Furthermore, understanding how tectonics influences human behavior is not solely of use to the study of the past. Data collected for this purpose are also useful in understanding tectonic processes and for addressing contemporary problems such as the vulnerability of critical engineering structures like chemical or nuclear facilities to earthquake hazard [U.S. Department of Energy, 1988; Wood and King, 1991]. Such information becomes particularly important in places like the British Isles, commonly but incorrectly thought to be inactive, where even a low probability of a major event poses a very serious hazard.

\section{Sediment Traps and Climatic Insensitivity}

Local concentrations of sediment or water are almost selfevidently advantageous to a variety of plant and animal species and to a range of human subsistence economies under a diversity of climatic regimes. Local sediment traps are characteristically formed in river catchments on geological structures subject to normal faulting or compressional folding (Figure 2). Active structures characteristically produce a series of local folds or uplifted blocks separated by troughs, with river profiles which alternate between stretches of down cutting of uplifted structures, and aggradation in the subsiding region between them. Climatically induced cycles of incision and aggradation are superimposed on this pattern, but it is the tectonic processes that determine the long-term pattern of erosion and sedimentation.

Topographic change and sediment traps are not exclusively associated with regions of active tectonics. Vertical motion due to isostatic depression and rebound in regions of continental glaciation may have analogous effects, as can sea level change in coastal regions. Whether they result from glacial or tectonic causes, nearly all these features are associated with rates of vertical movement of meters or tens of meters per 1000 years [Slemmons et al., 1991; Lambeck, 1990]. In regions of little activity, where the basic geometry of the landscape can be considered essentially static from the point of view of human land use, climatically induced and humanly induced changes in erosional and sedimentary regimes may take prominence. Indeed such regions can be said to be particularly vulnerable to such changes. Arid and semiarid regions are especially fragile environments, where relatively small climatic or anthropogenic effects may have catastrophic consequences for economic viability and human survival. Conversely, in arid regions which are tectonically active, sedimentary traps will acquire an enhanced attraction through a degree of insensitivity to changes of climate and land use, maintaining essentially stable environmental conditions for plant and animal life. The precise advantages of these sediment traps will vary depending on their size and other local factors but will tend to become greater in conditions where soil and water are limiting 


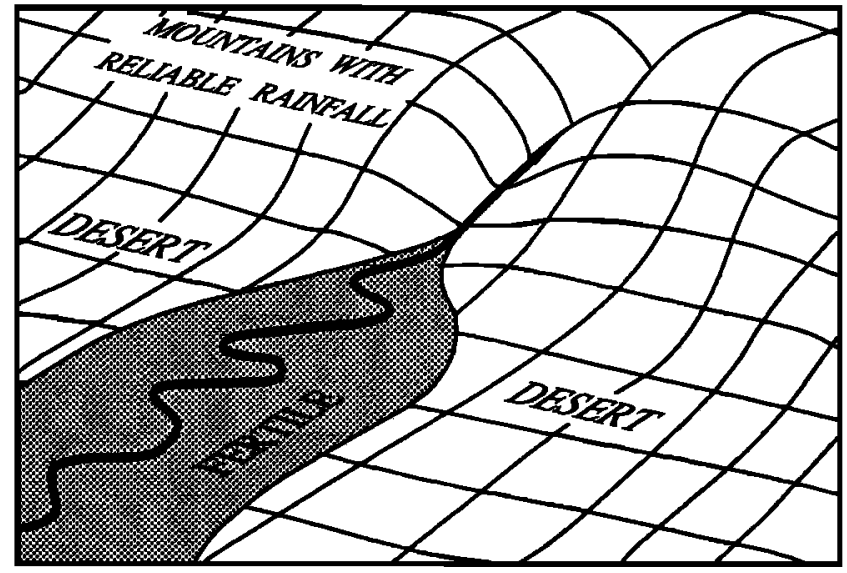

Figure 3. Many areas of prehistoric settlement are associated with localization on a regional as well as a local scale. A broader region of fertility is created from the outflow of water and sediment from a mountain range. The Nile Valley is one of the most dramatic examples of such an environment. Other examples are in East Africa (associated with the active rift valley), southern Siberia and Mongolia (associated with the active northern edge of the Himalayan system), the Middle East (associated with the Dead Sea rift, the Caucuses, Elborz or Zagros), or the Chilean valleys leaving the Andes. At these larger scales the role of rapid active tectonics is less obviously necessary. Mountains, once created, take many millions of years to disappear, and hence the lag between activity and the disappearance of environments takes longer. Moreover, regional localization is created not by topographic barriers but by desert. However, all of the above examples are associated with active tectonics, which can in some cases be shown to be important. For example, the active tectonics of Ethiopia are essential to create the heavy sediment load of the White Nile on which the lower valley depends for fertility.

factors and in regions which are otherwise environmentally fragile. Similar considerations apply at a much larger geographical scale, with regions of uplift providing rainfall catchment and a sediment supply which is concentrated in adjacent lowlands surrounded by an otherwise barren environment (Figure 3).

\section{Topographic Barriers and Herd Control}

The notion of topographic barriers as ecologically advantageous featuros is not intuitively obvious but follows from a consideration of humans as predators of medium and large sized mammals. One does not have to subscribe to a "Man the Hunter" view of human origins, with its overemphasis on meat eating and male activities, to recognize that dependence on animals as a source of subsistence has been a significant selective factor in the course of human evolution, and in the survival and expansion of human populations up to the present day. Yet animal prey pose a double problem for the human predator: of accessibility and of competition with other carnivores. This can be illustrated by taking the two extremes of the spectrum of "man-animal" relationships. At one extreme is scavenging, where the human population relies on other carnivores to do the difficult work of immobilization and takes what is left over. At the other extreme is full domestication in which the animal population is under permanent human con- trol and protection. In between are a range of ill-defined relationships commonly labeled as "hunting", which it is one of the main tasks of Pleistocene archaeology to explore and define.

Given that the initial reaction of a prey population to a predator is to flee, the hypothetically featureless plain offers a very poor chance of success to a technologically simple human hunter, unaided by efficient means of killing at a distance such as guns and horses or by constraints on animal movement such as fences or other artificial barriers. Fertile local environments such as sediment traps and lake basins may help to "tether" mobile prey to some extent but do not solve the problem of their ability to resist capture by flight or defence nor the problem of competition with other carnivores better adapted in body form to the needs of chase and attack. A complex topography with hill and mountain barriers, on the other hand, facilitates the monitoring, prediction, and control of animal movements, creates bottlenecks where prey can be located and trapped, and provides places to live or camp which are within easy access of the prey population but are hidden away so as to minimize disturbance of the animals; all features which an intelligent but otherwise unspecialized predator may be able to turn to advantage.

As in the discussion of sediment traps, tectonics plays a fundamental role in the creation of such landscape features, and these features may be advantageous both on a local scale (a matter of kilometers), where barriers are often juxtaposed with local sediment traps by the inherent nature of tectonic displacement and folding, and on a regional scale, where topographic barriers may circumscribe large blocks of favorable grazing terrain and confine the movements of animals within them [Sturdy, 1975].

\section{Paleolithic Epirus: Topography, Seismicity and Paleoenvironment}

Investigation of the Paleolithic archaeology of the Epirus region of northwest Greece over the past 30 years has been accompanied by an unusual emphasis on off-site archaeology and the reconstruction of local and regional paleolandscapes [Bailey, 1992; Bailey and Gamble, 1990; Bailey et al., 1983a, 1986a; 1990; Dakaris et al., 1964; Higgs, 1978; Higgs and Vita-Finzi, 1966; Higgs et al., 1967; Higgs and Webley, 1971; King and Bailey, 1985; Sturdy and Webley, 1988; VitaFinzi, 1978].

The topography of Epirus is rugged (Figure 4). A series of sharp ridges with elevations of $1000 \mathrm{~m}$ or more separate plateau regions that are in places deeply dissected by rivers. To the northwest in Albania and the northeast in the Pindus mountains, the terrain has higher elevations and even under the present interglacial conditions is relatively inaccessible. The region is bounded to the southwest by the Ionian Sea and to the south by the Gulf of Arta and the more subdued terrain of Akamania.

The seismicity map (Figure 1) shows that Epirus is subject to earthquakes with a rate of activity comparable to regions such as Japan, New Zealand and parts of the Middle East, where uplift rates of between meters and tens of meters per millennium are well established. Studies of both the earthquake mechanisms and the geology indicate a rogion subject to compression, and its broad features can be understood in such a context. However, more recent work indicates the importance of strike-slip motion to a more complete understanding of re- 


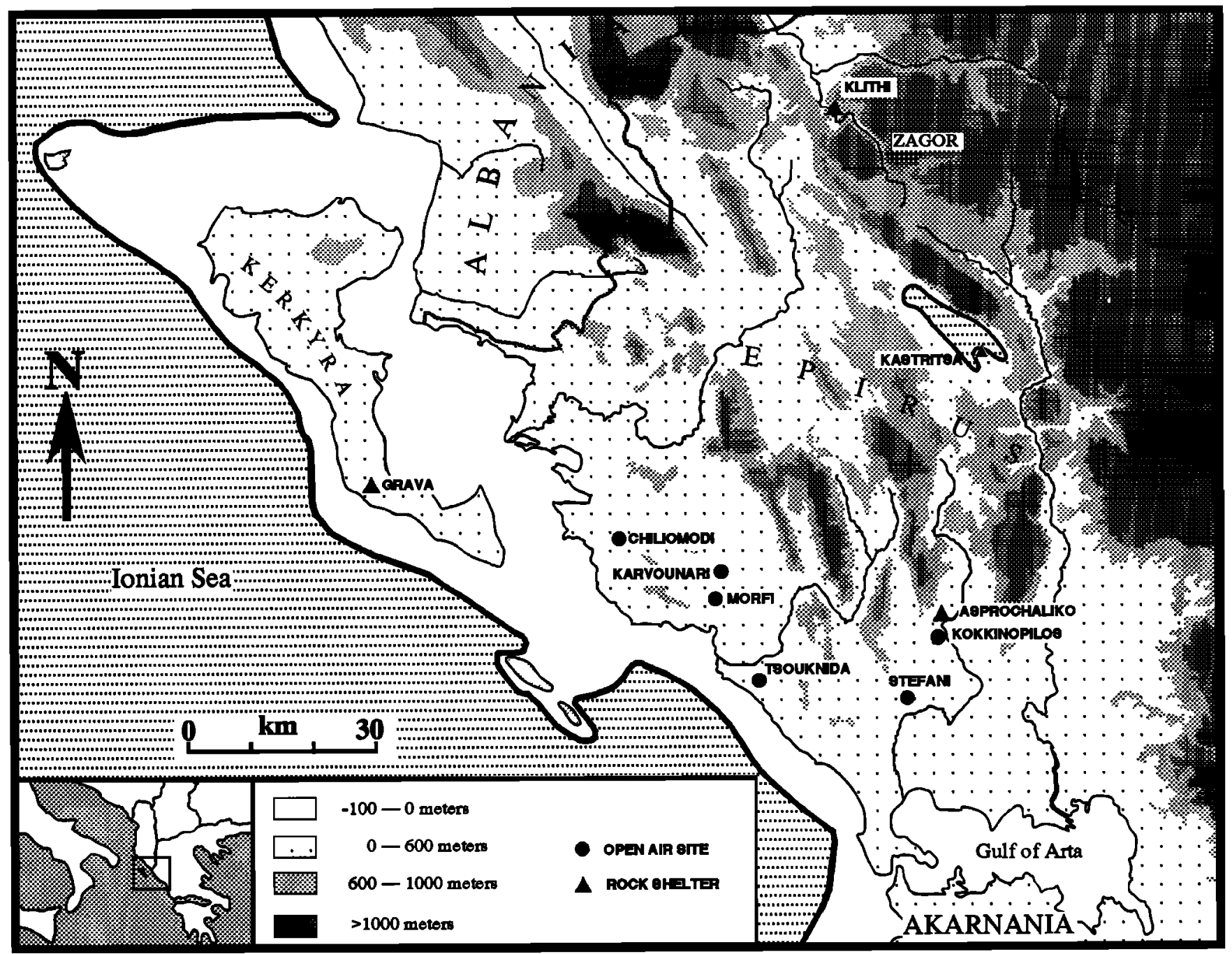

Figure 4. Topography of the Epirus region, showing principal Paleolithic sites mentioned in the text. The 100 meter contour is shown by a solid line to indicate the approximate sea level when the sites were active.

cent evolution of the topography [King et al., 1993]. The doformation is concentrated on a series of structures oriented roughly $20^{\circ} \mathrm{W}$ (Figure 5). The structures shown must extend into Albania, and seismicity indicates that features parallel to those on land must be active offshore. Although the features south of the Gulf of Arta have a similar strike, net compression gives way to the net extension that is characteristic of the Aegean and Peleponnese. Compression and uplift do, however, restrict the mouth of the Gulf of Arta and extend down the coast of Levkas.

Elements of the topography can be understood in terms of continuing tectonic evolution. The plateau-ridge system is associated with the telescoping of a series of fault-bounded limestone islands separated by sediment-filled marine basins. These basins have been uplifted by progressive tectonic movements to form flysch and flysch like rocks, which are the other dominant rock type alongside limestone. These are younger than the limestone and softer, with varying proportions of clay, silt, and siliceous material. They show spectacular folding and compression resulting from tectonic displacement. A schematic diagram of the evolution is shown in Figure 6, and the main features of the present geology are shown in Figure 7. The limestone regions are separated from regions of flysch by narrow limestone and flysch ridges that are the topographic expression of the most active fault zones.

On a more local scale, features such as Lake Ioannina or the Gulf of Arta are associated with active relative depression, and many more looal regions of subsidence can be identified. Uplift has resulted in spectacular gorges in some places with river profiles that alternate between downcutting and deposition over short distances [King et al., 1993].

The same processes continue offehore. Kerkyra (Corfu) is a limestone island, and rivers such as the Kalamas supply sediment that will become flysch when compacted and uplifted. The offshore tectonics is therefore a continuation of that seen on land. During the Last Glacial, when sea level receded, the land revealed would not have been a uniform plain, although the relief would have been more subdued than inland. Uplifted ridges would have been cut by valleys containing river terraces, with lakes and ponded sediments occurring between these features. For example, deposition in the Gulf of Arta could have continued throughout the glaciation as a result of active uplift at its mouth.

Different areas of the landscape have very different susceptibilities to tectonically induced uplift and subsidence. The limestone plateau regions are relatively undisturbed today 


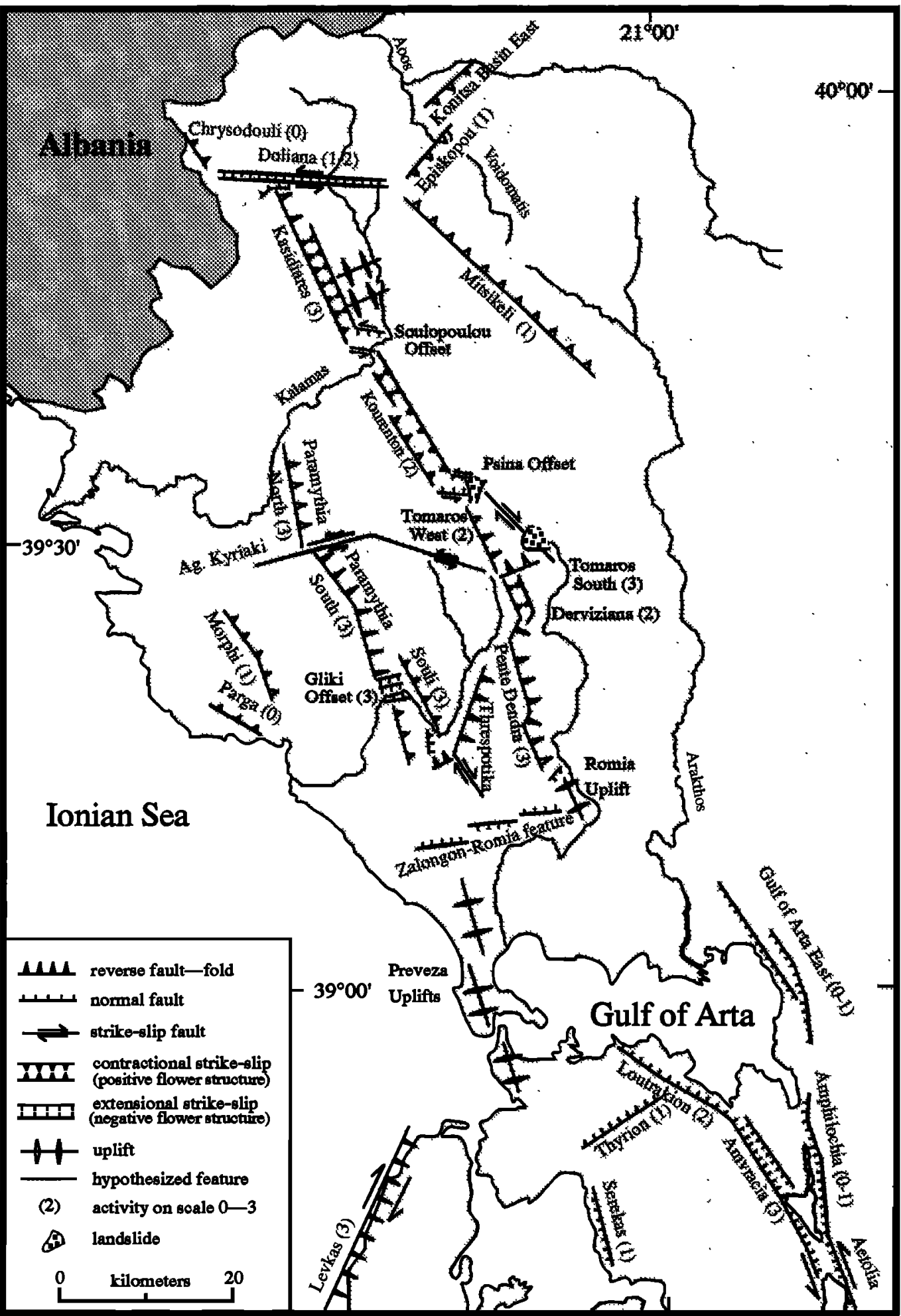

Figure 5. Active structures of the Epirus region. The structures are only shown where they have been reliably identified [King et al, 1993]. Particular areas of uncertainty are in the region northwest of the Kalamas river and in Albania where access to carry out field work has only recently become possible and remains hazardous in the border regions.

while the flysch being soft erodes almost as fast as it is uplifted to form a heavily gullied landscape.

Today Epirus is one of the wettest regions of Greece with annual precipitation ranging from about $900 \mathrm{~mm}$ on the coast to $1300 \mathrm{~mm}$ inland, a pronounced dry summer season, and extensive winter snow cover in the hinterland and at higher alti- tude. Pollen studies indicate that during the Last Glacial, cold and semiarid conditions prevailed with a vegetation of Artemisia steppe and occasional stands of evergreen oak and pine, creating a predominantly open, or at best a parkland, landscape [Bottema, 1974; Willis, 1989]. The combination of stoppe landscapes with high lake levels, as recorded, for ex- 

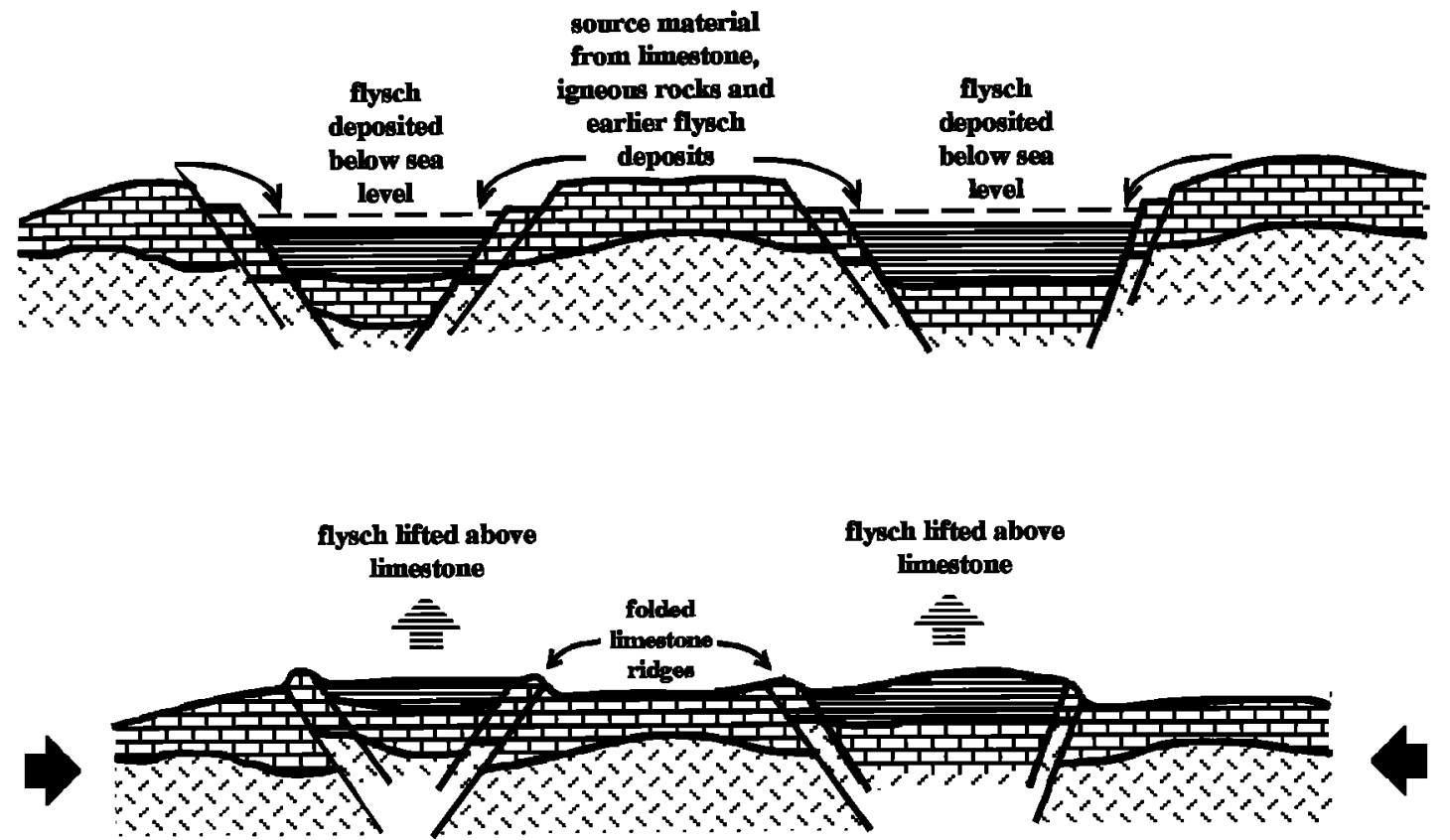

Figure 6. Schematic illustration of the geological evolution of Epirus, showing the way in which uplifting flysch basins are separated from limestone plateau areas by steeply folded limestone mountain ridges.

ample, by beach deposits in the Kastritsa rock shelter on the shores of Lake Ioannina, has been explained by a climate of cold winters, some $5^{\circ}$ to $6^{\circ} \mathrm{C}$ colder than at present, high winter precipitation, and summer aridity with temperatures $2^{\circ}$ to $3^{\circ} \mathrm{C}$ lower and less precipitation than today [Prentice et al., 1992]. The Pindus mountains created locally wetter conditions providing refuges for deciduous tree species, although the latter probably persisted only as isolated stands in protected localities, for example, on the south facing cliffs of the Vikos Gorge [Bennett et al., 1991; Willis, 1989]. Glacial moraines on the heights of the Pindus have been linked to valley-fill sediments which can be dated to between about $28 \mathrm{kyr}$ and $16 \mathrm{kyr}$, and the presence of local glaciation seems to have created conditions severe enough to inhibit any human use of the upland interior at the Last Glacial Maximum, i.e., from $\sim 20 \mathrm{kyr}$ to $16 \mathrm{kyr}$ [Bailey et al., 1990; Lewin et al., 1991; Woodward, 1990]. Low plant biomass, snow cover in winter, and water availability in summer would clearly have been important ecological limiting factors, with a major impact on regional population movements and individual settlement locations.

\section{Archaeology and Palaeoeconomy}

The interpretation of Paleolithic site distributions has been dominated by the hypothesis of seasonal transhumance, in which the rock shelters of Asprochaliko and Kastritsa were interpreted as the winter and summer camps, respectively, of people who followed herds of red deer in their seasonal migrations between coast and hinterland [Higgs et al, 1967]. The paleoenvironmental data that have become available since then have, if anything, reinforced the environmental basis for this hypothesis, emphasising the low plant and animal biomass on a regional scale, and the seasonal contrast between aummer and winter climates, and between coast and hinterland.

Subsequent archaeological investigations, however, have refined this picture through new archaeological surveys, excavations, radiometric dates, and faunal analyses, particularly at Klithi (Figure 4), demonstrating greater complexity and variability in the palaeoeconomy through time and space [Bailey, 1992]. Settlement in lowland areas and near the coast is of long duration and includes numerous sites with evidence of Middle Paleolithic ( $200-40 \mathrm{kyr})$ and Upper Paleolithic ( 40$10 \mathrm{kyr}$ ) industries. The Asprochaliko rock shelter (Figure 4) has a 6-m-thick sequence of deposits dated at the base by thermoluminescence dating to $100 \mathrm{kyr}$ and evidence of intensive if intermittent use during the Middle and Upper Paleolithic and some evidence in the uppermost levels of continued use into the later prehistoric and historical periods [Higgs and VitaFinzi, 1966; Bailey et al., 1983b; Huxtable et al., 1992]. The nearby site of Kokkinopilos is an expanse of open-air red sediment which has been variously subjected to uplift, erosion, gullying and redeposition. The sequence here is still in dispute [cf. Bailey et al., 1992; Dakaris et al., 1964; Higgs and Vita-Finzi, 1966; Runnels and Van Andel, 1993; Harris and Vita-Finzi, 1968], but artefacts of all periods from perhaps as early as $\mathbf{2 5 0} \mathbf{k y r}$ through to Roman and later are present on the surface and in gully sections. Similar open-air sites have been identified at Morfi and at other locations in lowland Epirus and on Kerkyra, while other inhabited rockshelters in the lowlands include the site of Grava [Sordinas, 1969].

In the hinterland, by contrast, Middle Paleolithic industries are absent, apart from isolated finds of individual artefacts. The earliest finds at the base of the 7-m-thick deposit at the Kastritsa rock shelter are dated to $20 \mathrm{kyr}$, and the richest concentration of artefacts and faunal remains is in the upper levels dated between $16 \mathrm{kyr}$ and $12 \mathrm{kyr}$ [Bailey et al., 1983b]. At the Klithi rock shelter there is a rich 2-m-thick sequence dated between $16 \mathrm{kyr}$ and $10 \mathrm{kyr}$ resting on $5 \mathrm{~m}$ of culturally sterile deposits [Bailey et al., 1986b; Bailey and Thomas, 1987].

Overall, the main focus of settlement and land use throughout the Paleolithic sequence was at low altitude and near the coast. The country in the hinterland and at higher altitude ap- 


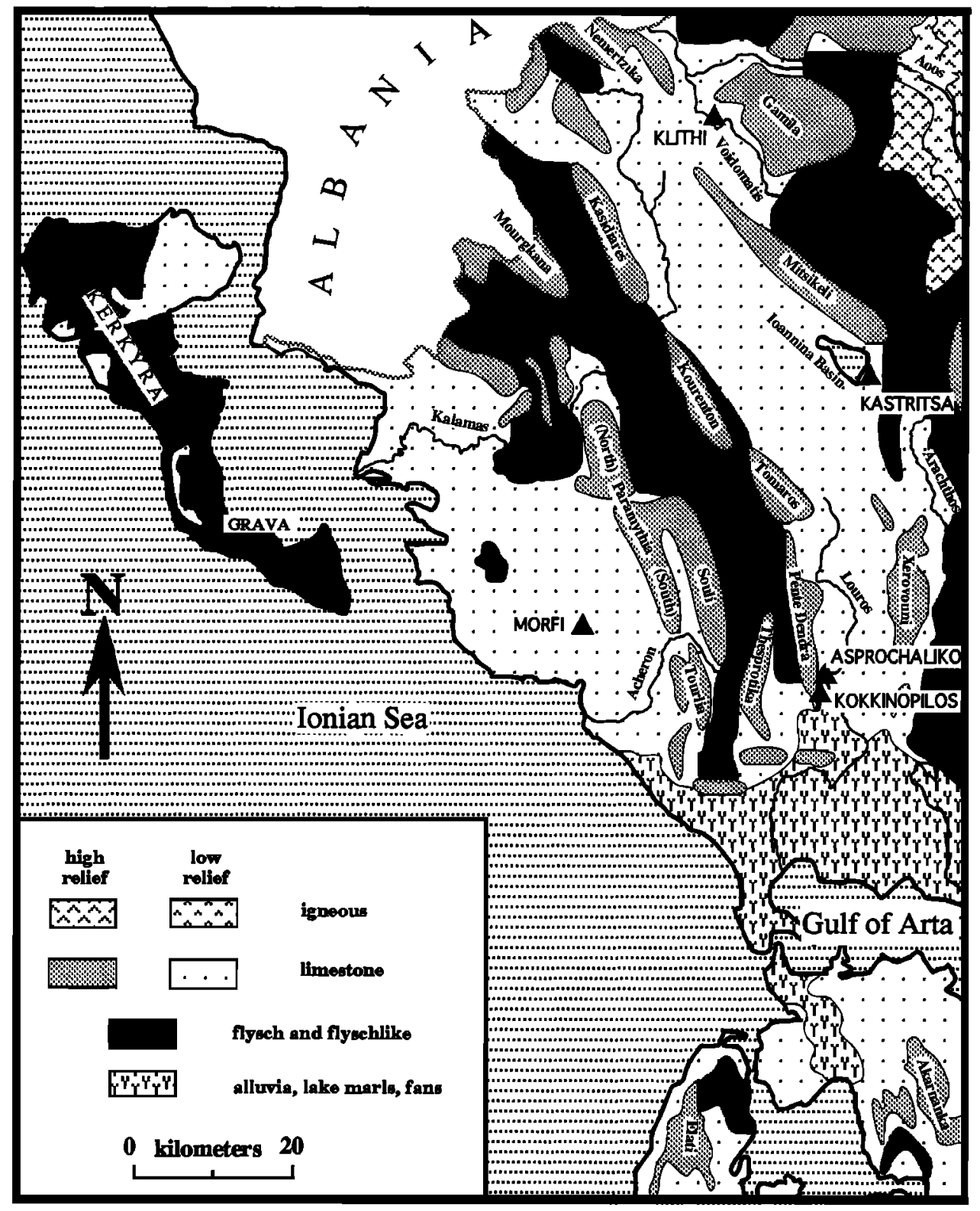

Figure 7. Schematic geology of the Epirus region.

pears to have been ignored or visited only sporadically until after the Last Glacial Maximum ( $20-16 \mathrm{kyr})$. Only from about 16 kyr onward was there intensive use of the hinterland, most probably on a seasonal basis, in the vicinity of sites such as Kastritsa and Klithi.

Faunal remains show a greater diversity than predicted by the original transhumance hypothesis, largely reflecting differences in local site topography and animal habitats. Ibex is at least as common in the Upper Paleolithic levels at Asprochaliko as red deer [Bailey et al., 1983b]; bovids and equids appear well represented at Grava [Sordinas, 1969] and at Kastritsa; the large faunal collection from Klithi is dominated by remains of ibex and chamois [Bailey et al., 1986a], and wild pigs are present in low frequency at several sites. In view of the environmental constraints discussed above, it is likely that all these species would have made seasonal migratory movements of some degree, with deer and equids travelling over the longest distances, pig the shortest, and ibex and chamois shifting altitudinal range over relatively restricted distances. Hence it is likely that seasonal mobility would have dominated land use strategies, although this need not have involved herd following in the strict sense, nor need it have been shaped solely by the movements of red deer. Plant foods or marine resources appear to have made very little contribution to the palaeoeconomy [Bailey et al., 1983a].

Camivores are represented by bones of lion, lynx, wolf, fox, and pine marten, which would have been potential competitors with human populations. They appear to have made virtually no contribution to the accumulation of the archaeological bone assemblages, however, at least by the end of the Upper Paleolithic period (to judge from the Klithi assemblage) where evidence of carnivore bone chewing or modification is almost totally absent.

\section{Regional Barriers and Animal Distributions}

Understanding the distribution of animals in the Paleolithic landscape is a matter of combining the known or inferred habi- 


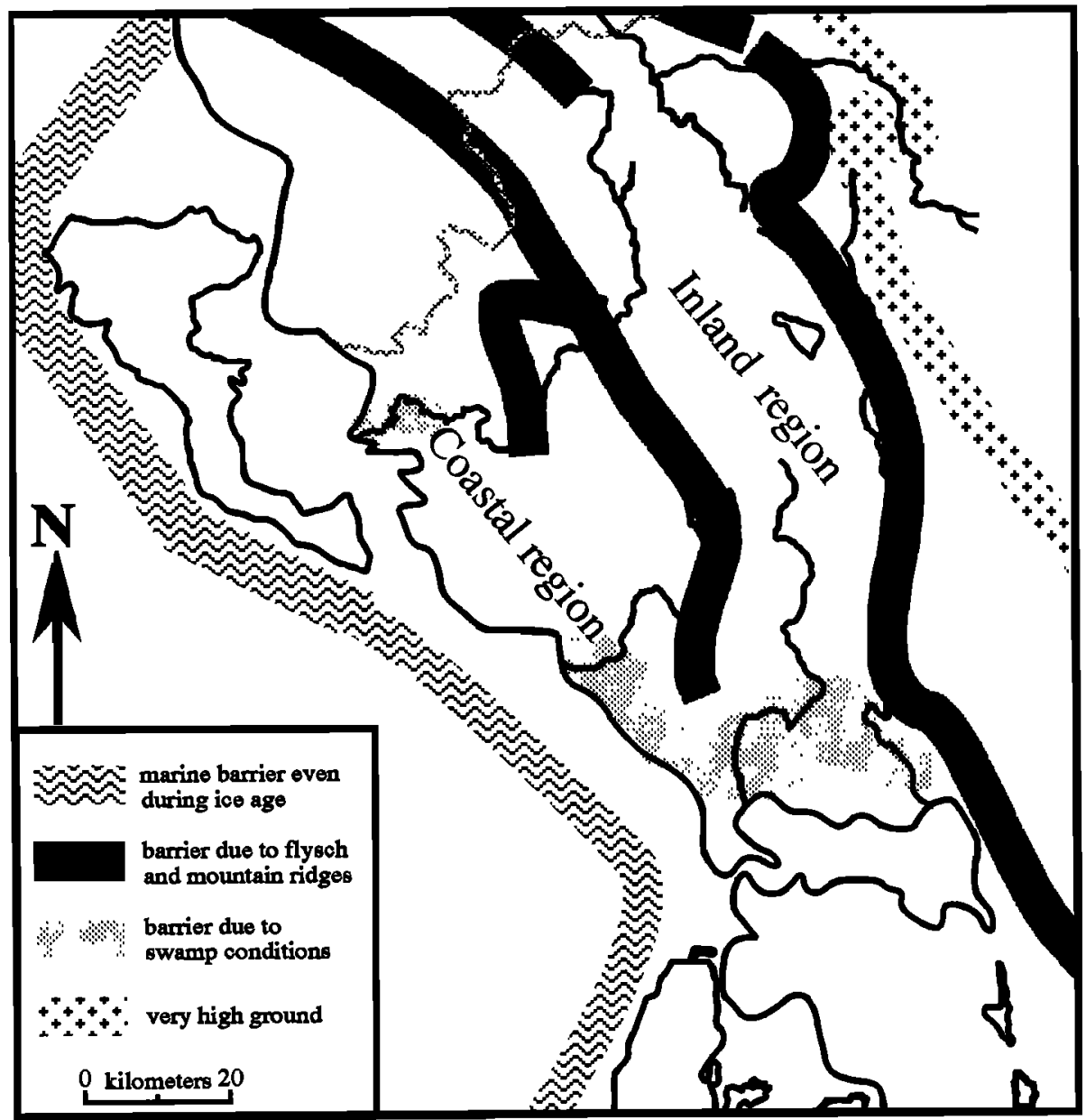

Figure 8. Simplified physical barriers of the Epirus region.

tat proferences and behavior of the various species with subdivisions of the landscape based on their relative edaphic potential (i.e., their potential to provide food and essential nutrients for animals). To determine edaphic categories, we rely on the underlying geology, soils where these are known to have existed during the Pleistocene, terrain, and general climatic and vegetational parameters supplied by pollen data. These have been examined in considerable detail by Sturdy and Webley [1988].

Soils on the limestone plateaux are thin and patchy, except where sediments are concentrated in small basins, but they are the most favorable for vegetation that is attractive to animals. Soluble phosphate, the principal vegetational contribution to the calcium compounds from which growing animals make bones, is between 2 and 4 times higher than in the flysch soils, and only the limestone soils have adequate trace elements for animal growth such as copper and cobalt [Sturdy and Webley, 1988]. In contrast, the flysch, because of uplift and erosion, produces only thin and ranker soils, and their edaphic quality is low. It is important to emphasize that this characteristic of the flysch only applies to environments which are subject to disturbance by tectonic factors. In stable environments productive soils eventually develop on the flysch, and this potential can be realised on a small scale in Epirus by terracing and intensive horticultural practices in the vicinity of villages. On a large scale, however, the extensive flysch basins have a poor grazing potential for animals and have been treated as marginal for this purpose even in recent and historical times, whereas the limestone continues to be extensively grazed.

Unlike Epirus, flysch landscapes in an tectonic environment in North Island, New Zealand, have been used extensively for sheep and cattle since the early 1950 es but only as a result of top dressing from the air with the trace elements the flysch soils lack [Gibbs, 1964]. The withdrawal of government subsidies for appropriate aircraft in the 1980s is causing much of this land to become unproductive. The natural thick vegetation on the flysch of New Zealand or Epirus superficially seems to be an ideal habitat for herbivorous mammals, compared to the thin vegetation on the limestone areas. We are, however, observing cause and effect. The limestone areas become heavily grazed because they are attractive to animals, while the adjacent flysch is relatively untouched.

Precipitation and temperatures were never such as to create a desert-bounded environment of the type indicated in Figure 3. However, topography and geology create analogous barriers (Figure 8). The narrow limestone ridges have very steep profiles and form scree slopes and cliffs which act as formidable barriers to human and animal movement. The inadequacy of disturbed flysch to develop soils that produce satisfactory feedstock for herbivorous mammals could have inhibited animal movements as effectively as desert barriers in arid regions.

The effect of these barriers in combination with areas favorable for grazing reveals a large horseshoe-shaped area of grazing for the larger animals, enclosed by barriers of mountain, 


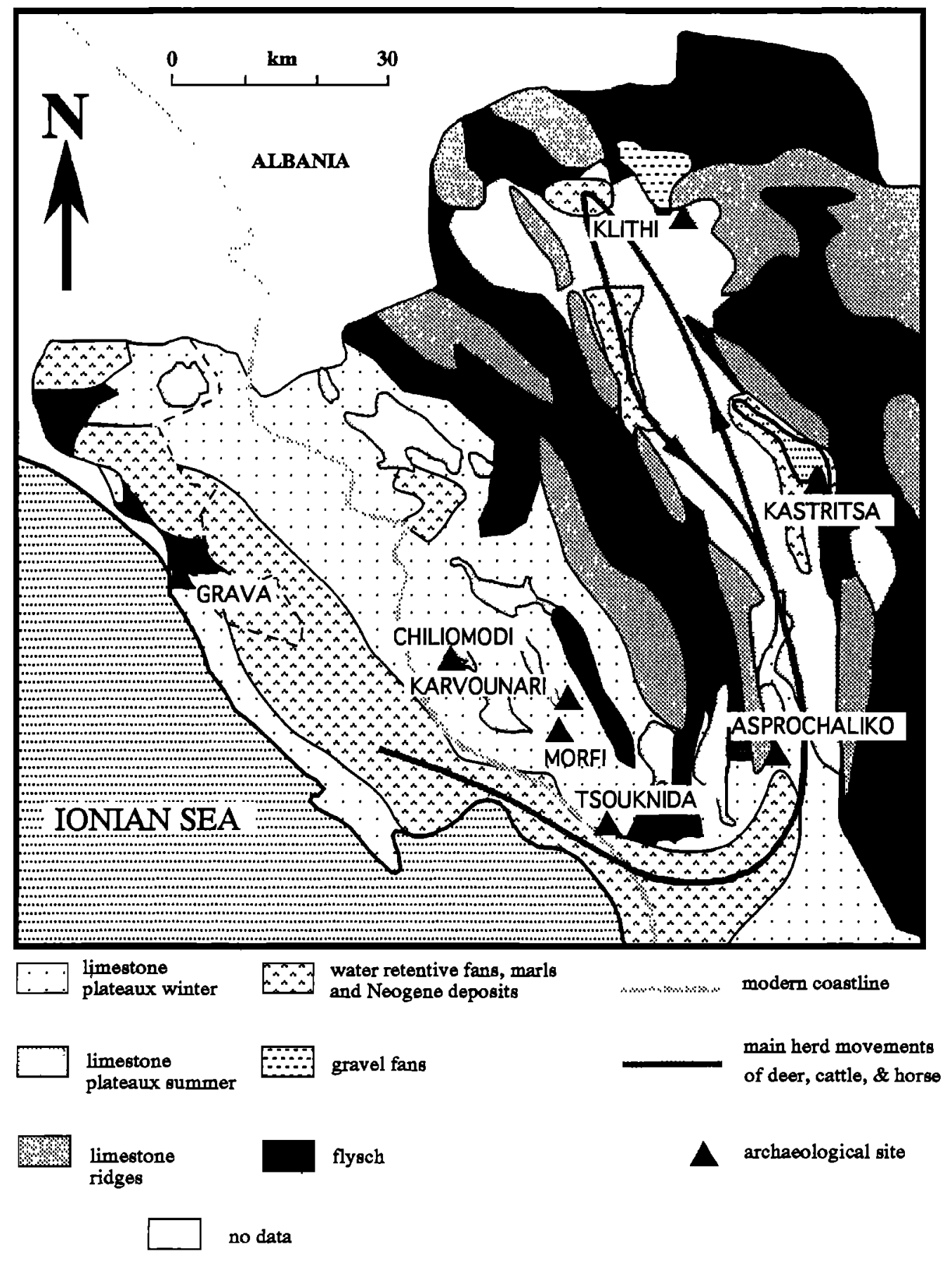

Fignre 9. Simplified map of regional terrain categories of Epirus, showing annual range of movements of main herd animals (deer, cattle, and horse). Movements of ibex and chamois would have been more localized, with distinct annual ranges in the hinterland and nearer the coast. The water retentive areas shown for the coastal region comprise mostly terrestrial fan and marine Neogene sediments below present sea level and on Kerkyra. The latter have edaphic characteristics similar to the flysch but tend to produce deeper and maturer soil profiles. The information on this map is a simplification of the full study of the region which in addition to geology includes mape of altitude, slope angles, dissection, snow lines, and water retentiveness [Bailey, 1994]. Derived from these and studies of soil samples are maps of edaphics and the likely locations of animals at different times of year. Migration routes are based on this information.

sea, and flysch (Figure 9). The eastern arm of the horseshoe is an area of gentle limestone topography, forming an ideal grazing territory for the larger herbivores, bounded to the southwest by a flysch barrier, and to the north and east by mountains and flysch, reinforced by permanent ice fields at high elevation. These topographic features have the effect of making the eastern area of accessible grazing an effective cul-de-sac some $100 \mathrm{~km}$ long by $10-20 \mathrm{~km}$ wide, with important consequences for the control and prediction of animal movements. This is all the more significant given that deer, cattle, and horse could only have used this area during summer because of the severity of the Last Glacial winters. 

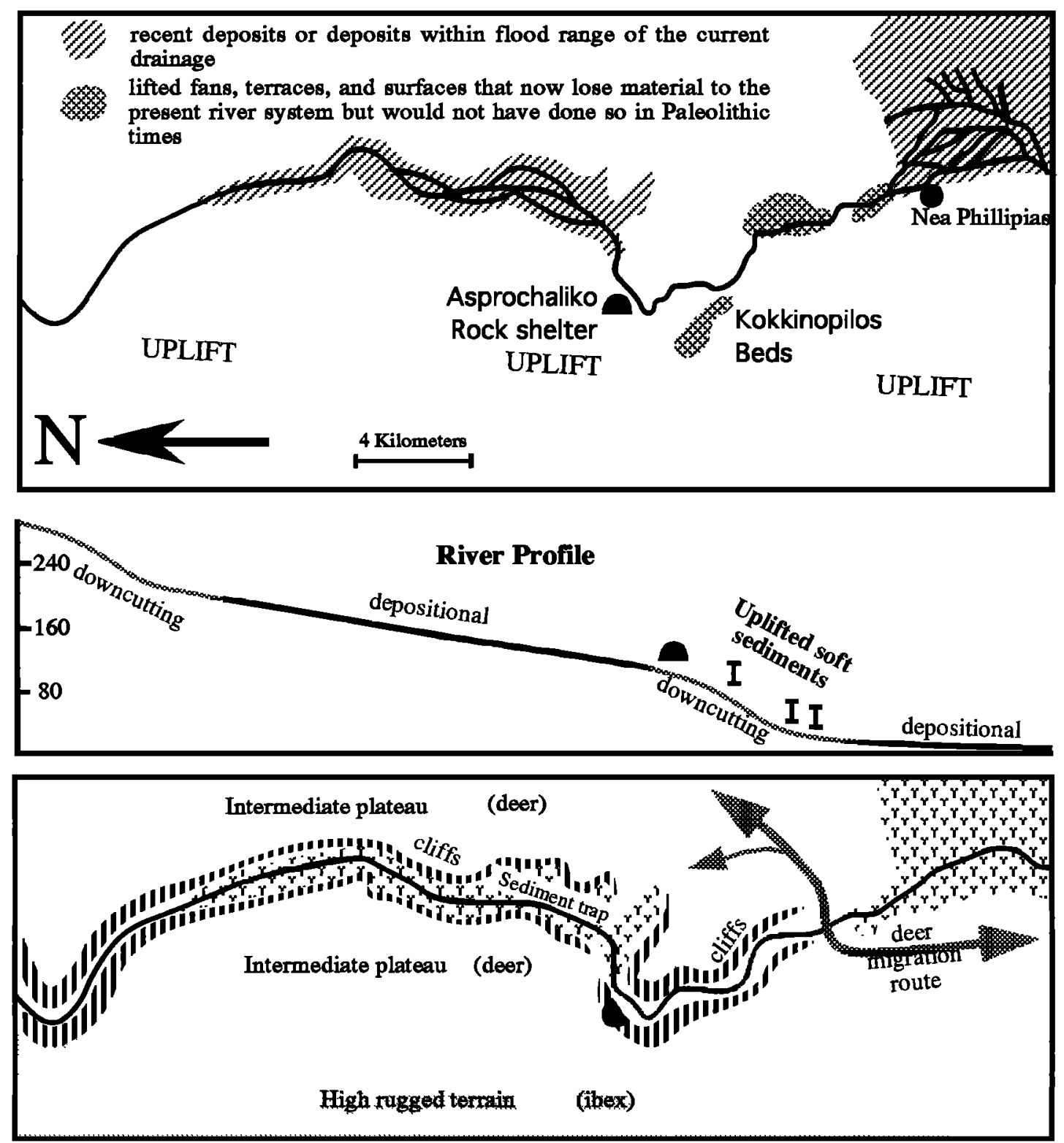

Figure 10a. Localization of topographic features at Asprochaliko and their relationship to animal movements. (top) The course of the Louros river together with areas where active sedimentation is taking place. Areas of uplifted sediments that were earier at or near river level are indicated. (middle) The profile of the river bed indicating regions of uplift and downcutting. The similarity of these profiles to those found in regions where uplift is closely associated with recent earthquakes [King and Vita-Finzi, 1981; King and Stein, 1983; Stein and King, 1984] should be noted. (bottom) An interpretation of how the environment was used. The information provided in the figures is based on detailed mapping as described in the Figure 9 caption.

The westem arm would have formed a similar large-scale enclosure of limestone plateaux, with optimal conditions for use in winter. To the west the Ionian sea forms a barrier, while flysch and sharp topographic ridges delimit the northern and eastern margins. To the north, the mountainous topography and a steeply shelving coastline would have limited accessibility, even at the lowered sea level of the Last Glacial Maximum. Low swampy ground in large basins like the area of the Gulf of Arta would also have played an important role in controlling human and animal movements: in summer the infestation of insects would have powerfully stimulated seasonal herd dispersal, while the availability of scrub and shrub vegetation along its margins would have provided important attractions in winter in the form of browse for deer and cattle.

\section{Local Site Environments}

This phenomenon of topographic and edaphic enclosure is reproduced at a smaller geographical scale in relation to the immediate surroundings of individual sites. Asprochaliko is in a small gorge hidden away to the west of the main deer migration routes but well placed to intercept deer diverting from the main route into a small enclosed limestone plateau west of the site (Figure 10). This would have provided attractive spring grazing, especially for older stags and hinds, which are the animals most likely to leave the main herd at this season. The well-watered sediment trap to the northeast would also have been attractive toward the end of the summer, when dry conditions would have reduced grazing opportunities elsewhere, and lower temperatures were beginning to drive the 

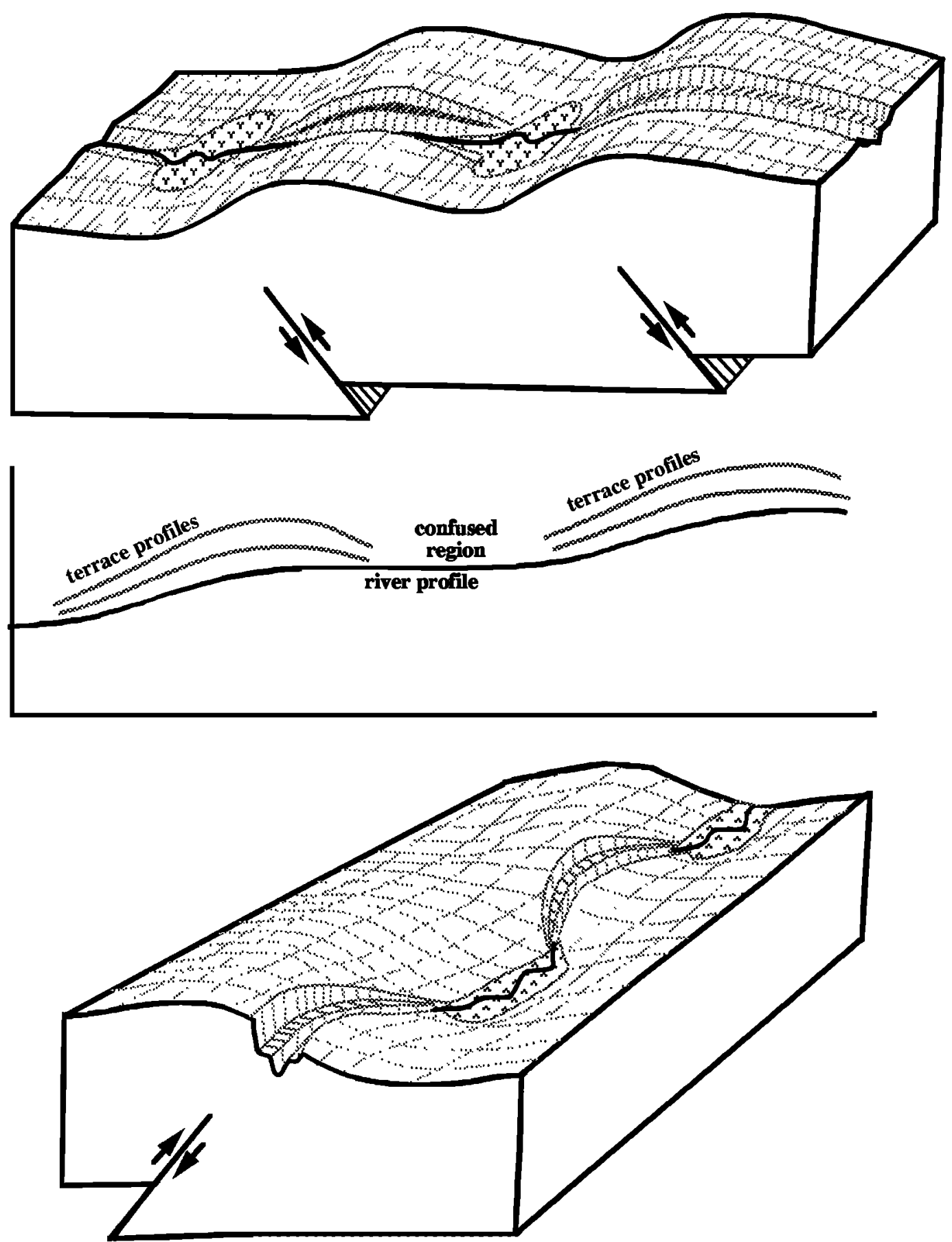

Figure 10b. Two possible tectonic interpretations for the Asprochaliko-Kokkinopilos region are shown. (top) The river cuts directly across rising anticlines. (bottom) The river meanders toward and away from a single uplifting anticline. King and Bailey [1985] entertained both possibilities but favored the former. However, a broader view of the tectonics of Epirus [King et al., 1993] now favors the second. It is important to appreciate that deformation of the form shown is superimposed on a preexisting topography left by earlier tectonic processes. Thus, for example, the Louros river follows a valley inherited from much earlier times, and tectonic activity merely determines how it is currently being modified.

herds back toward their winter territories nearer the coast. The site is also well placed to intercept ibex in local movements from high ground in the northwest to lower and more sheltered terrain in the southeast.

Kastritsa is on the northwest slope of a limestone "island" protruding through lake sediments and partly surrounded by the waters of the lake (Figure 11). Shallow gravel fans and wa- ter retentive lake sediments fringing the open water would have attracted horse and cattle, respectively, with deer concentrating on the gentle limestone terrain to the south and west, feeding closer to the lake at the end of the summer. As at Asprochaliko, the site is placed to one side of the main migration routes but also controls a local enclosure formed by the eastern arm of the lake and steeper ground farther to the east 


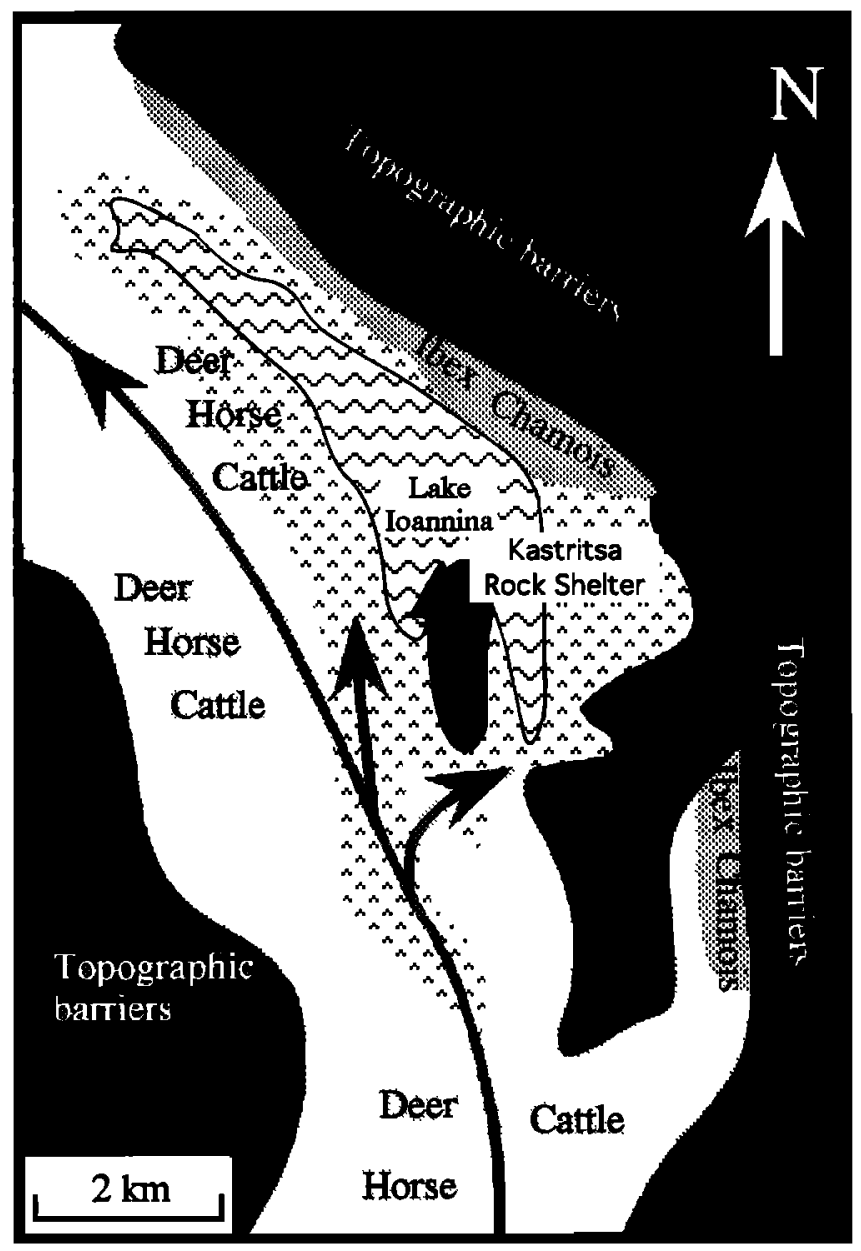

Figure 11. Hypothesized animal distribution and movements near to the Kastritsa rock shelter (cave) site. A corridor suitable for deer, horse, and cattle crosses the region from the southeast to the northwest. The outline of Lake Ioannina shows the extent of the lake in Paleolithic times. The rock shelter is located near to the nose of an anticline that extended into the lake. Topographic barriers and flysch which represent areas that are difficult for animals to traverse or exploit appear to the west and northwest and to the southwest. Ibex and Chamois terrain is restricted to hill slopes to the east and northeast. The information provided in the figures is based on detailed mapping as described in the Figure 9 caption.

and north, while being secluded from it. Deer is most numerous among the bone remains, while cattle and horse are important secondary species, and the presence of all major anatomical elements suggests that the animals were killed nearby, rather than at more distant locations [Kotzambopoulou, 1988]. The site location offers a combination of attractions facilitating exploitation of all three species: local enclosure, a locally fertile and water retentive environment, and strategic but secluded proximity to routes of animal movement.

Similarly Klithi (Figure 12) is in a sheltered gorge, close to, but out of the way of, the main routes of seasonal movement of chamois and ibex but well placed to control their movements into and out of an enclosed area of high summer grazing. The faunal remains suggest a very effective exploitation, with the introduction of whole carcasses into the site [Bailey et al., 1986a]. In addition, the occurrence of isolated

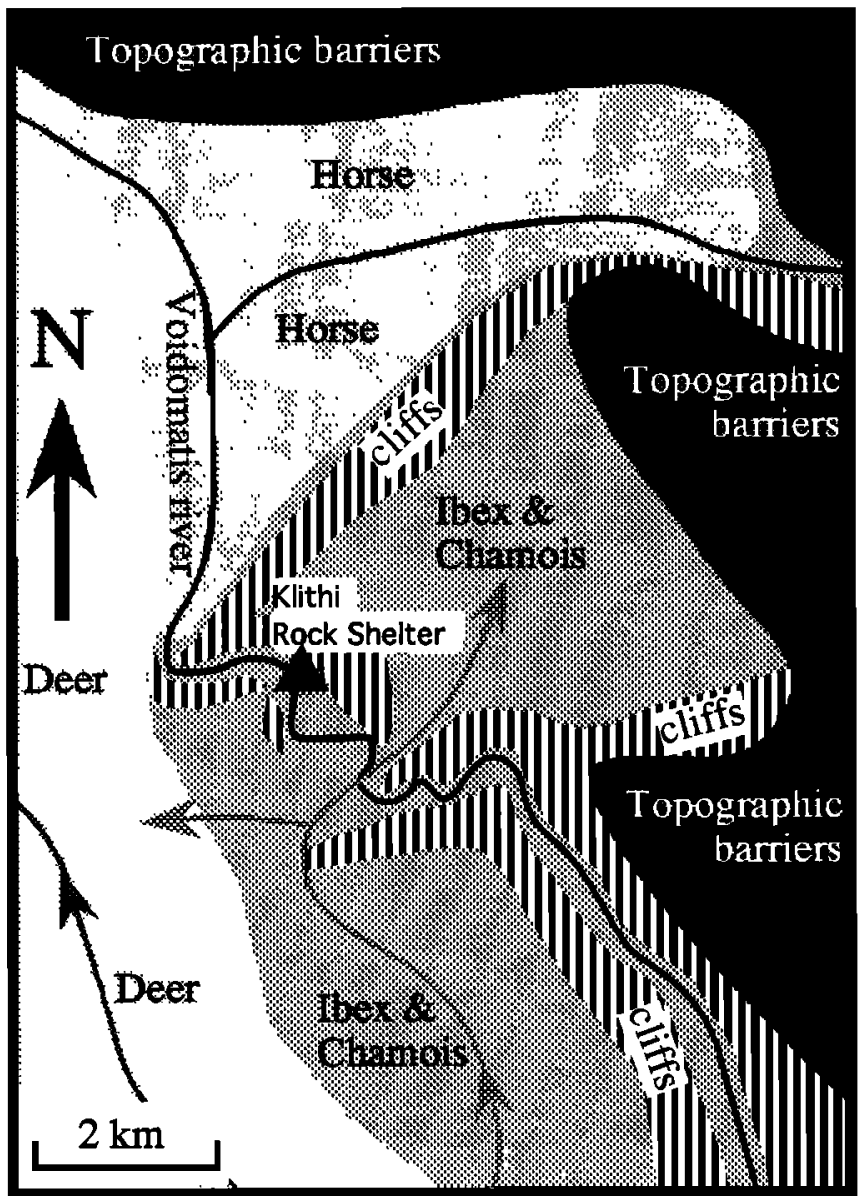

Figure 12. Hypothesized animal distribution and movements near to the Klithi rock shelter (cave) site. Deer and horse terrains appear close to the site. The site itself is in a gorge surrounded by ibex and chamois country. Topographic barriers which represent areas that are difficult to traverse appear to the north and east. Cliffs are indicated separately from general topographic barriers and consist of slopes that are so extreme that, except for a few places, are totally impassable even to ibex or chamois. The information provided in the figures is based on detailed mapping as described in the Figure 9 caption.

deer bones associated with artefacts in the neighboring rock shelter of Megalakkos and at the mouth of the nearby plain suggests that the area may also have been important in monitoring deer movements at the extreme of their summer range to the west. The alluvial sediments that filled the valley in front of the site and extended out over the large Konitsa basin to the northwest appear to have consisted of active outwash gravels during the period when the site was occupied, between $16 \mathrm{kyr}$ and $10 \mathrm{kyr}$, and presented a bare and stony landscape with perhaps at best a light spring flush of fine grasses. The finer sediments and soils which provide a fertile basis for present-day agriculture are of late Holocene data [Lewin et al., 1991; Sturdy and Webley, 1988]. This represents an important difference from the other two sites but is consistent with the emphasis on ibex in the site fauna. These animals are less critically dependent on water supplies than the larger herbivores and could have mitigated any effects of summer aridity by moving to high altitude pastures. 


\section{Long-Term Dynamics}

The above reconstructions describe the average conditions for the Last Glacial, and as such give a largely static picture of the landscape and of human economic activities within it. However, in assessing the long-term success of human and other populations in the regional environment, it is not so much the average conditions that are relevant as the shorterterm fluctuations, and especially the extremes in the range of such variability [King and Lindh, 1994]. It is these extremes that are critical in defining the selective pressures which shape longer term trends, giving a competitive edge to those species and populations which are better equipped to cope with periods of environmental deterioration, and hence aro better placed to respond rapidly when environmental conditions improve.

Winter cold and snow cover, especially in bad winters, is an obvious limiting factor of the Last Glacial environment, which would have placed a high premium on conditions of local sheiter or at low altitude. The rock shelter of Asprochaliko has long been recognized, with its south facing aspect, as a favorable location for winter use [Legge, 1972]. The south facing Klithi in its protected gorge offers a similar attraction, important even in the summer months for habitation near high-altitude terrrain in close proximity to a permanent ice field. Recent paleoenvironmental data underline this point while also demonstrating that summer aridity would have been another powerful limiting factor, placing an equally high premium on areas of water-retentive sediments. The importance of tectonics in sustaining local areas of fertility under these circumstances cannot be overemphasized. The fact that the three sites discussed offer advantages of shelter, access to locally fertile and well-watered sediments, or both is thus of great significance. By controlling those local areas of the landscape best protected against extremes of cold and aridity, the human population would have been well placed to cope with temporal variability in environmental conditions, both the large-scale changes associated with the Last Glacial Maximum, when aridity and cold would have been at their maximum and smaller-scale fluctuations from year to year.

The hinterland region, being available for humans on only a seasonal basis, was probably always a marginal area for human exploitation. It certainly appears to have been visited only sporadically until quite late in the regional sequence of Paleolithic occupation, and was therefore an area in which other carnivores could have competed successfully for prey. With climatic deterioration at the Last Glacial Maximum, all animal activity in the hinterland would have been severely restricted, and the carnivores would have been forced into the coastal lowlands into closer competition with humans who were already well established there. When conditions began to improve again after $16 \mathrm{kyr}$, the human population, by virtue of their ability to control key topographic features in the landscape, would have been able to respond quickly and thus to secure and maintain an increasingly effective control of the hinterland region and its seasonal population of herbivorous mammals. To the extent that deformation has not simply created those features of the landscape that human populations have turned to their advantage but has also actively sustained and even accentuated them during the course of human occupation, active tectonics needs to be considered as an important agent in human-environment interactions, with far-reaching consequences for an understanding of other processes: climatic, vegetational, cultural, and social.

\section{Conclusions}

The essential tectonic style of northwest Greece has produced limestone plateau areas which are separated from each other by regions less attractive to humans and animals, whether because they are steep, narrow mountains or the gullied terrain and unproductive soils of the Epirus flysch. At present this is certainly reflected in the distribution of Paleolithic sites. Cave sites are almost bound to be in limestone, but the large number of small and large open sites are also all on the limestone plateaux of westem or eastern Epirus. So far there have been no discoveries of Paleolithic artefacts in the flysch basins. The association of inland grazing areas, which are both attractive to herbivores and surrounded by natural topographic barriers, would have been particularly advantageous to the human monitoring and control of animal rosources. Large sediment basins, notably the Gulf of Arta region, are also likely to have persisted as important areas of attraction, with a fertility periodically renewed by tectonic processes and effectively independent of climatic changes. These features of topographic barriers, attractive grazing areas, and climatically insensitive sediment traps are reproduced at a smaller scale in relation to individual site locations, with local enclosures, discreetly placed camp sites, and small concentrations of sediment accumulation facilitating the attraction, observation, and control of animals.

The inferred constraints placed on animal distribution and movement at various seasons by physical barriers have more general consequences for the techniques of human exploitation of herbivores. The location of sites in the complex landscape of Epirus has been discussed largely within the timescale of anatomically modern humans. But there is no reason why such an approach should not contribute a valuable understanding to much earlier periods and other parts of the world. The ecological and evolutionary "drama" has traditionally been viewed in terms of ecological interactions between human populations and the biological organisms which provide food or act as predators, competitors and parasites. Quaternary climatic and vegetational change typically provide changes of scenery and may frequently be more active "players". Changes in the solid earth, however, have been treated as external, adventitious, and disruptive, causing a temporary halt in production or a change of venue but not otherwise actively shaping the performance. This view is clearly oversimplifed, and tectonios, like other environmental or biological processes, needs to be more actively incorporated as a variable shaping the longterm interactions which affect the course of human evolution. Uplift can divert the course of rivers or cause them to create deeply incised channels. Fold and fault fronts produce local enclosures or natural fences. Such features lead to a complex topography which, by channelling or reatricting animal movements, offers much more potential than a featureless plain to a predator that must use its wits to be competitive. In the complex topography of tectonically active areas, the human brain had the resources to fashion a unique technical competitiveness.

Aclmowledements. Fieldwort was supported by grants from the British Academy, the British School at Athens, the National Geographic Society, and the Society of Antiquaries and by permits iseued through the good officen of the British School at Athens, the Ministry of Culture, Athens, the Institute of Geological and Mineralogical Research (IGME), Athens, the Ephoreia of Palaeoanthropology and Speleology, Athens, and the Ephoreia of Prehistoric and Classical Archaoology, 
Iosmine. Wo are grateful to the Oxford Radiocarbon Accelerator Unit and the British Museum for radiometric dating. The tectonic part of this work was carried out within the fremework of the ARCHAEOMEDES Projoct, funded by DG XII of the European Commission as part of the Environment (Desertification) Programme under contraet BV5V-0021.

\section{References}

Ambraseys, N.N., Temporary seismic quiescence: S.E. Turtey, Geophys. J. Ent, 96, 311-331, 1989.

Bailey, GN., The Palaeolithic of Klithi in its wider context, Annu. Br. Sch. Archaeol Athens, 87, 1-28, 1992.

Bailoy, GN, Excavations at Klitht, 1983-1988: Palaeolithic archaeology and landscapes in Epirus, northwest Greece, McDonald Institute, Cambridgo, in press, 1994.

Bailey, G.N., and C.S. Gamble, The Balkana at 18000 B.P.: The view from Epirus, in The World at 18000 BP, vol.1, edited by C. Gamble and O. Soffer, pp.148-167, Unwin and Hymm, Boston, Mass., 1990.

Bailey, G.N, and G. Thoma, The use of percussion drilling to obtain core samples from rookshelter deposits, Antiquity, 61, 430-439, 1987.

Bailoy, G.N., P.L. Carter, C.S. Gamble, and H.P. Higgs, Epirus revisited: Seasonality and inter-site variation in the Upper Palaeolithic of northwest Greece, in Hunter-Gatherer Economy in Prehistory: A Buropean Perspective, edited by G.N. Bailey, pp. 6478, Cambridge University Press, Now York, 1983a.

Bailey, G.N, P.L. Carter, C.S. Gamble, and H.P. Higga, Asprochaliko and Kastritsa: Further investigations of Palaeolithic settlement and economy in Epirus (north-west Greece), Proc. Prehist. Soc., 49, 1542, $1983 b$.

Bailey, G.N., P.L. Carter, C.S. Gamble, H.P. Higga, and C. Roubet, Palaeolithic investigations in Epirus: The results of the first season's excavations at Klithi, 1983, Anrus. Br. Sch. Archaeol. Athens, 79, 722, 1984.

Bailey, G.N., C.S. Gamble, H.P. Higgs, C. Roubet, D.A. Sturdy, and D.P.Webley, Palaeolithic investigations at Klithi: Preliminary results of the 1984-1985 field seasons, Avru. Br. Sch. Archaeol Athens, 81, $7-35,1986$ a.

Bailey, G.N., C.S. Gamble, H.P. Higgs, C. Roubet, D.P. Wobley, J.A.J. Gowlett, D.A. Sturdy, and C. Tumer, Dating results from Palaeolithic sites and palaecenvironments in Epirus (north-west Greece), in Archaeological Results from Accelerator Dating, edited by J.A.J. Gowlett and R.E.M. Hedges, pp. 99-107, Oxford University Committee for Archaeology, Oxford, 1986b.

Bailey, G.N., J. Lowin, M.G. Macklin, and J.C. Woodward, The 'Older Fill' of the Voïdomatis valley, north-west Greece and its relationship to the Palaoolithio archacology and glacial history of the region, J.Archaeol.Sci., 17, 145-150, 1990.

Bailoy, G.N., V. Papaconstantinou, and D.A. Sturdy, Asprochaliko and Kotkinopilos: TL dating and reinterprotation of Middle Palacolithic sites in Epirus, north-west Greoce, Cambridge Archaeol. J., 2, 13644, 1992.

Bennett, K.D., P.C. Tzedakis, and K.J. Willis, Quaternary refugia of north Europesn trees, J. Biogeogr., 18, 103-115, 1991.

Bottema, S., Late Quaternary Vegetation History of Northwesterm Greece, Groningen University Press, Groningen, Netherlands, 1974.

Dakaris, SI., E.S. Higgs, and R.W. Hey, The climate, environment and industries of Stono Ago Groece, part I, Proc. Prehist. Soc., 30, 199244, 1964.

DeMets, C., R.G. Gordon, D.F. Argus, and R.S. Stein, Curront plate motions, Int. Geophys. J., 101, 425-478, 1990.

Gibbs, H.S., Soils of Northland, in New Zealand Natural Resources Survey, pp.25-37, Govermment Printer, Wellington, New Zealand, 1964.

Hardy, D.A, Kellex, J., Galanopoulos, V.P., Flemming, N.C, and T.H. Druitt (Eds.), Thera and the Aegean World, III, Proceedings of the Third International Congress, Santorini, Greece, 3-9 September 1989, wol. 2, Earth Sciences, Thera Foundation, London, 1989.

Harris, D.R, and C. Vita-Finzi, Kokkinopilog-A Greek badland, Geogr. $J ., 134,537-546,1968$.
Higgs, E.S, Environmental changes in northern Groece, in The Environmental History of the Near and Middle East since the Last Ice Age, odited by W.C. Brice, Pp. 41-49, Academic, San Diego, Calif., 1978.

Higgs, E.S, and C. Vita-Finzi, The olimate, environment and industries of Stone Age Groece, part II, Proc. Prehist. Şoc., 32, 1-29, 1966.

Higgs, E.S., and D.P. Webley, Further information concerning the onvironment of Palaeolithic man in Epirus, Proc. Prehist. Soc., 37, 367-380, 1971.

Higgs, E.S., C. Vita-Finzi, D.R. Harris, and A.E. Fagg, The climate, environment and industries of Stone Age Greece, part II, Proc. Prehist. Soc., 33, 1-29, 1967.

Huxtable, J., J.A.J. Gowlett, G.N. Bailey, P.L. Carter, and V. Papaconstantinou, Thermoluminescence dates and a new analysis of the early Mousterian from Asprochaliko, CurTent Arthropol., 33, 109-14, 1992.

King, G.C.P., and G.N. Bailey, The palaecenvironment of some archaeological sites in Greece: The influence of accumulatod uplift in a seismically active region, Proc. Prehist. Soc., 51, 273-82, 1985.

King, G.C.P., and A.G. Lindh, Prodictability and the evolution of culture, in Time and Transformations, Proceedings of the Cambridge Conference on Dynamical Descriptions and Human Systems, edited by S. Van der Leeuw, Routledge, Boston, in press, 1994.

King, G.C.P., and R.S. Stein, Surface folding, deformation rate, and earthquake repeat time in a reverse faulting environment: The Coalinga, Califomia, earthquake of May 2, 1983, in The 1983 Coalinga, California Earthquakes, Calif. Div. Mines Geol. Spec. Publ. 66, 165-176, 1983.

King, G.C.P., and C. Vita-Finzi, Active folding in the Algerian earthquake of 10 October, 1980, Nature, 292, 22-26, 1981.

King, G.C.P., D.A. Sturdy, and J. Whitney. Landseape geometry and the active tectonics of northwest Groece, Bull. Geol. Soc. Am, 105, 137$161,1993$.

Kotzambopoulou, E., Faunal analysis of the Kastritsa Cavo, Greece, M.Phil. thesis, Cambridge University, Cambridge, Englend, 1988.

Lambeck, K., Late Pleistocene, Holocene and present sea-levels: Constraints on future change, Palaeogeogr. Palaeoclimatol. Palaeoecol., 89, 205-217, 1990.

Logge, A.J., Cave climatee, in Papers in Economic Prehistory, edited by E.S. Higgs, pp. 97-103, Cambridge University Press, Now York, 1972.

Lowin, J., M.G. Macklin \& J.C. Woodward, Late Quaternary fluvial sedimentation in the Voïdomatis basin, Epirus, Northwest Greece, Quatemary Research, 35, 103-115, 1991.

Madeyska, $T$., The distribution of human settlement in the extra-tropical Old World $24000-15000$ BP, The World at 18000 BP, vol. 2, edited by C. Gamble and O. Soffer, pp, 24-37, Unwin and Hyman, Boston, Mass., 1990.

Moseley, M.E., The good old days were better: Agrarian collapse and tectonics, Am. Anthropol, 85, 773-799, 1983.

Moseley, M.E, and R.A. Feldmen, Fighing, farming and the foundation of Andoan civilization, in The Archaeology of Prehistoric Coastlines, edited by G. Bailey and J. Parkington, pp. 125-134, Cambridge University Press, Now York, 1988.

Prentice, I.C., J. Guiot, and S.P. Harrison, Mediterranean vegetation, lake leveis and palaeoclimate at the Last Glacial Maximum, Nature, $360,658-60,1992$.

Runnels, C., and T. Van Andel, A handaxe from Kolkinopilos, Epirus, and its implications for the Palaeolithic of Greoce, J. Field Archaeol., 20, 191-203, 1993.

Slemmons, D.B., E.R. Engdahl, M.D. Zoback, and D.D. Blackwell (Eds.), The Neotectonics of North America, Decade Map, vol. 1, Geological Society of America, Boulder, Col., 1991.

Sordinas, A., Investigations of the prehistory of Corfu during 1964-1966, Balkan Stud., 10, 393-424, 1969.

Stein, R.S., and G.C.P. King, Seismic potential revesled by surface folding: The 1983 Coalinga, California, oarthquake, Science, 224, 869-872, 1984.

Sturdy, D.A., Some reindeer economies in prehistoric Europe, in 
Palaeocconomy, edited by B.S. Higgs, pp. 55-95, Cambridge University Press, New York, 1975.

Sturdy, D.A., and D.P.Webley, Palaeolithic geography: Or where are the doer?, World ArchaeoL 19, 262-280, 1988.

U.S. Department of Energy, Office of Scientific and Technical Information, Site Characterization Plan, Yucea Mountain Site, Nevada Research and Development Area, Nevada, Oak Ridge, Tenn., 1988.

Valansise, G., Geological records of combined tectonic processes in the central Santa Cruz Mountains, roport, U.S.G.S., Menlo Part, Calif., 1992.

Vita-Finzi, C., The Mediterranean Valleys: Geological Changes in Historical Times, Cambridge University Press, New Yort, 1969.

Vita-Finzi, C., Archaeological Sites in Their Setting. Thames and Hudson, London, 1978.

Willis, KJ., Late Quaternary vegetation history of Epirus northwest Greece, Ph.D. dissertation, Cambridge University, Cambridge, England, 1989.

Wood, R.M., and G.C.P. King, An empirical data base for the investigation of earthquake-related changes in crustal hydrology, paper presented at the Second International High-Lovel Radioactive Waste
Management Conference, American Nuclear Society, Las Vogas, Nov. 1991.

Woodward, J., Late Quaternary sedimentary environments in the Voïdomatis Basin, northwest Greece, Ph.D. dissertation, Cambridge University, Cambridge, England, 1990.

Zhang, P., M. Ellis, D.B. Slemmons, and F. Mao, Right-lateral displacements and the Holocene slip rate associated with prehistoric earthquakes along the southern Panamint Valloy fault zone: Implications for southom Basin and Range tectonics and coastal Califomia deformation, J. Geophys. Res., 95, 4857-4872, 1990.

G. Bailey, Department of Archaeology. University of Cambridge, Downing Street, Cambridge CB2 3DZ, England. (e-mail: GNB2@phx.cam.ac.uk)

G. King, Institut de Physique du Globe, 5 rue Rene Descartes, 67084 Strasbourg, France. (e-mail: king(1)klakmuf.u-strasbg.fr)

D. Sturdy, Department of Archeoological Sciences, University of Liverpool, P.O. Box 147, Liverpool L69 3BX, England.

(Received March 29, 1993; revised December 8, 1993; accepted January 28, 1994.) 